\title{
KESESUAIAN POLA CELANA SISTEM CHARMANT PADA WANITA DEWASA INDONESIA BERTUBUH IDEAL
}

\author{
Hanifah $^{1^{*}}$, Ernawati $^{2^{*}}$ \\ Program Studi Pendidikan Kesejahteraan Keluarga, Jurusan Ilmu Kesejahteraan Keluarga \\ Fakultas Pariwisata dan Perhotelan \\ Universitas Negeri Padang \\ Jl. Prof. Dr. Hamta, Air Tawar Padang, Kel. Air Tawar Barat, Kec. Padang Utara, Kota Padang, Kode Pos 25171 \\ Sumatera Barat. Indonesia \\ Email: hnifah96@gmail.com
}

\begin{abstract}
Abstrak
Tujuan penelitian untuk mendeskripsikan kelemahan, cara memperbaiki, serta kesesuaian pola celana wanita sistem Charmant terhadap wanita bertubuh ideal Indonesia. Metode penelitian yang digunakan adalah penelitian terapan. Objek penelitian yaitu pola celana wanita sistem Charmant yang diuji cobakan pada wanita bertubuh ideal Indonesia, dengan tinggi $165 \mathrm{~cm}$, berat $57 \mathrm{~kg}$. Dinilai oleh 5 orang panelis yang ahli dibidang pola busana wanita. Instrumen penelitian yang digunakan adalah kuesioner/angket memakai skala likerts. Teknik analisa data menggunakan statistik deskriptif berupa perhitungan rumus persentase menggunakan microsoft exel. Hasil penelitian menunjukkan pola celana wanita sistem Charmant terhadap wanita bertubuh ideal Indonesia, mempunyai 2 kelemahan berdasarkan penilaian dari 5 orang panelis diantaranya yaitu: 1) lingkar duduk sempit $4 \mathrm{~cm}$, 2) tinggi duduk panjang $3 \mathrm{~cm}$. Cara memperbaikinya yaitu: 1) lingkar duduk ditambahkan $1 \mathrm{~cm}$ pada pola depan dan belakang, 2) tinggi duduk dikurangi sebanyak $3 \mathrm{~cm}$.
\end{abstract}

Kata Kunci: kesesuaian, celana, charmant, wanita ideal.

\begin{abstract}
The purpose of this study is to describe the weaknesses, how to improve, and the suitability of Charment'swomen's skrit pattern towards ideal Indonesian female posture. The method uses applied study. The data analysis was performed using descriptive statistics in the form of calculating formula percentages using Microsoft Excel. The object of this study was the Charmant's women skirt pattern which were tested on an ideal Indonesian female posture, with a height of $165 \mathrm{~cm}$, weight of $57 \mathrm{~kg}$. Judged by 5 panelists who are experts in women's clothing. The study instrument was a questionnaire / questionnaire using the Likerts scale. The results showed that the Charmant'swomen skirt pattern towards an ideal Indonesian female posture had 5 weaknesses based on the assessment from 5 panelists which were : 1) circumference narrow sitting of $3 \mathrm{~cm}$, 2) sitting high over $3 \mathrm{~cm}$. How to improve it are: 1 cireumference narrow sitting add by $1 \mathrm{~cm}$ on the front and back side, 2) sitting high shortened by $3 \mathrm{~cm}$.
\end{abstract}

Keyword: suitability, skirt, charmant, ideal woman posture.

\section{PENDAHULUAN}

Pola celana wanita sistem Charmant berasal dari Belanda (Porrie, 2003:6). Bentuk dan ukuran tubuh orang Belanda berbeda dengan bentuk dan ukuran tubuh tubuh orang Indonesia. Bentuk dan ukuran tubuh orang Belanda lebih besar dari orang Indonesia. Ini di dukung oleh hasil penelitian communication risk factor collaboration NCD-Risc 2016, yang menyatakan untuk kelahiran tahun 1996 tinggi rata-rata wanita Belanda adalah $168 \mathrm{~cm}$ dan pria Belandanya adalah 182,5 sedangkan tinggi rata-rata wanita Indonesia adalah 152 $\mathrm{cm}$ dan pria Indonesia adalah 163,5 cm (Beritagar.id : 2017).
Berdasarkan penjelasan diatas terlihat perbedaan tinggi tubuh wanita Belanda dengan tinggi tubuh wanita Indonesia. Dengan adanya perbedaan ukuran tubuh wanita Belanda dengan wanita Indonesia tersebut, maka perlu dilakukan penyesuaian.

Dalam pemilihan pola juga disesuaikan dengan bentuk tubuh seseorang, karena bentuk tubuh merupakan salah satu aspek yang harus diperhatikan dalam pembuatan busana. Hal ini disebabkan tidak semua model dan sistem pola dapat dipakai oleh semua bentuk tubuh, karena ada kelebihan dan kelemahannya. Secara garis besar bentuk tubuh wanita dikelompokkan menjadi tiga kelompok yaitu kurus, ideal dan gemuk. Untuk menentukan bentuk dan ukuran tubuh tersebut terlebih 
dahulu harus dilakukan pengukuran berat badan. Berat badan ideal sering menjadi dambaan setiap orang. Berat badan ideal adalah dimana berat badan seseorang berada pada posisi sesuai dengan tinggi badannya.

Untuk mengetahui berat tubuh yang ideal bisa menggunakan rumus Body Mass Index (BMI) atau Indeks Masa Tubuh (IMT). Rumus ini memadukan perhitungan antara tinggi badan dengan berat badan seseorang, sehingga hasilnya akan menjadi berat ideal orang tersebut. Seperti yang dikemukakan oleh Sunardi (2015:54) cara sederhana menghitung berat badan ideal menggunakan indeks masa tubuh (IMT) dengan menggunakan rumus sebagai berikut:

$$
\mathrm{IMT}=\frac{\text { Berat badan }(\mathrm{kg})}{\mathrm{TB}(\mathrm{m}) \times \mathrm{TB}(\mathrm{m})}
$$

Demikian juga celana yang baik dipengaruhi oleh sistem pembuatan pola celana. Salah satu sistem untuk membuat pola celana yaitu sistem pola Charmant. Sistem pola celana Charmant memiliki kelebihan seperti pembuatan pola celana yang lebih praktis digunakan karena memakai 6 jenis ukuran yaitu lingkar pinggang, lingkar duduk, tinggi pesak, lingkar kaki celana, panjang sisi luar dan tinggi panggul.

Jurusan Ilmu kesejahteraan Keluarga FPP UNP, sistem Charmant belum digunakan dalam pembuatan pakaian. Pola celana sistem Charmant belum pernah dipraktekkan dalam pembuatan celana, khususnya di program studi Pendidikan Kesejahteraan Keluarga konsentrasi Tata Busana. Padahal pola tersebut merupakan salah satu bentuk pola yang bisa digunakan untuk pembuatan celana.

Perbedaan pola celana sistem Charmant dengan pola celana sistem lain dapat dilihat dari ukuran yang dibutuhkan, cara mengambil ukuran, dan teknik pembuatan pola. Dengan adanya ukuran dan ketentuan dalam pembuatan pola, belum dapat dipastikan bahwa pola tersebut sesuai dengan bentuk tubuh sipemakai, karena setiap sistem mempunyai cara tersendiri dalam proses pembuatan pola.

Selain sistem pembuatan pola, pemilihan bahan juga mendukung hasil celana karena jika bahan yang digunakan tidak sesuai dengan pemakainya maka akan mempengaruhi hasil celana tersebut. Bahan yang sesuai untuk pembuatan celana ini adalah bahan yang tebal, mempunyai tenunan yang rapat dan lembut. Karena bila menggunakan bahan yang tipis seperti satin, sutra akan mempengaruhi jatuhnya celana yang dihasilkan.
Agar pakaian yang dikenakan pas dan bagus terlebih dahulu harus melakukan pengepasan atau fitting. Menurut Poespo (2000:72) "Fitting menunjukkan pada sempit dan longgarnya sebuah bentuk busana dalam hubungannya orang yang memakai". Fitting bertujuan untuk mengetahui pas atau tidak pasnya pakaian pada tubuh sipemakai. Fitting dilakukan beberapa kali, supaya pola benar-benar tepat dan pas digunakan untuk tubuh wanita ideal di Indonesia. Apabila terjadi ketidaksesuaian maka harus dilakukan perbaikan pada pola.

Berdasarkan pra eksperimen yang penulis lakukan dalam pembuatan pola celana sistem Charmant pada wanita dewasa Indonesia bertubuh ideal dengan tinggi 165 dan berat badan $57 \mathrm{~kg}$ yang berumur 25 tahun. Dapat diketahui bahwa terdapat kelemahan yaitu pada bagian lingkar duduk sempit $2 \mathrm{~cm}$, lingkar lutut dan lingkar kaki besar $4 \mathrm{~cm}$. Dari pada itu maka celana sistem Charmant ini diperlukan analisis atau penelitian lebih lanjut agar tercipta pola yang lebih baik.

\section{KAJIAN TEORI}

\section{Pola Celana}

Menurut Pratiwi (2001:3) menyatakan "Pola adalah potongan kain atau kertas tersebut mengikuti ukuran atau bentuk badan tertentu. Pernyataan ini didukung oleh pendapat Porrie Muliawan (2002:2) yang mendefenisikan "Pattern atau pola dalam bidang jahit menjahit sebagai suatu potongan kain atau potongan kertas yang dipakai sebagai contoh untuk membuat baju ketika bahan digunting".Selanjutnya menurut Haswita (2000:25) "Pola pakaian adalah gambaran bentuk dasar pakaian yang di buat dengan ukuran tertentu. Pola pakaian tersebut terdiri dari pola badan, pola rok, maupun pola celana".

Dari beberapa pengertian diatas, dapat disimpulkan bahwa pola adalah gambaran bentuk tubuh seseorang mulai dari pola badan, lengan, rok maupun celana, yang dibuat sedemikian rupa sesuai ukuran tubuh seseorang dan biasanya dibuat dari kertas atau kain yang dijadikan contoh pada saat menggunting.

Sedangkan celana menurut Pratiwi (2001:70) "Celana adalah busana bagian bawah mulai dari pinggang kebawah sampai mata kaki dan mempunyai pipa untuk memasukkan kaki”. Menurut (Goet Poespo 2000) "Celana adalah pakaian luar yang menutupi badan dari pinggang ke mata kaki dalam dua bagian kaki yang terpisah".

Jadi pola celana adalah gambaran bentuk tubuh seseorang yang menutupi pada bagian bawah yang 
terdiri dari dua pipa untuk memasukkan kaki yang disatukan oleh pesak dibuat dari kertas atau kain.

\section{Pola Celana Sistem Charmant}

Pola celana sistem Charmant adalah salah satu teknik pembuatan pola yang berasal dari Belanda (Charmant, 1990:12). Untuk mendapatkan bentuk celana sesuai model maka perlu dibuat polanya. Untuk mendapatkan pola celana sesuai bentuk tubuh maka diperlukan macam-macam ukuran sesuai sistem.

Adapun sistem pola celana Charmant (1990:22) membutuhkan ukuran sebagai berikut: 1) lingkar pinggang, 2) lingkar duduk, 3) tinggi pesak, 4) lingkar kaki celana, 5) panjang sisi luar dan 6) tinggi pinggul.

\section{Penyesuaian Pola}

Untuk mengetahui kesesuaian suatu pola dilakukan dengan cara melakukan pengepasan atau fitting. Menurut Wancik (1996:31) bahwa "Fitting adalah mencoba pakaian untuk mengetahui apakah pakaian sudah betul ukuran dan modelnya ketika dipakai". Sedangkan Poespo (2000:72) "Fitting menunjukkan pada sempit dan longgarnya sebuah bentuk busana dalam hubungannya dengan orang yang memakainya.

Busana atau pakaian yang enak dipakai adalah yang berukuran tepat dan tidak kesesakkan ataupun kedodoran/longgar bila dikenakan". Haswita (1999:28) mengatakan "Sebagus atau sebaik apapun sehelei pakaian, tetapi bila tidak pas atau sesuai bagi sipemakai tidak ada artinya”.

Berdasarkan penjelasan diatas dapat disimpulkan fitting merupakan kegiatan yang perlu dilakukan dalam pembuatan busana bertujuan untuk melihat cocok atau tidaknya dengan ukuran tubuh model atau sipemakai. Fitting dilakukan berulang kali, kemudian pola diperbaiki sesuai dengan hasil fitting sehingga menghasilkan pola yang sesuai dengan badan model.

Setelah fitting dilakukan, apabila ditemui ketidaksesuaian maka perlu dilakukan perbaikan terhadap pola sehingga menghasilkan celana yang sesuai dengan badan model.

\section{METODE PENELITIAN}

Penelitian ini tergolong penelitian terapan. menerapkan dan mengungkapkan keadaan yang sebenarnya dari suatu teori/objek untuk mengungkapkan kekurangannya sebagai dasar dalam memecahkan masalah dalam penyusunan dan perbaikan.

Dalam pembuatan pola celana dilakukan analisa terhadap kekurangan dan kelebihanya sehingga terbentuk suatu pola yang sesuai dan dapat diaplikasikan untuk wanita bertubuh ideal Indonesia. penelitian ini terdiri dari satu variabel yaitu: "Kesesuaian pola celana sistem Charmant pada wanita dewasa Indonesia bertubuh Ideal", dengan indikator pola celana.

Objek penelitian adalah pola celana Sistem Charmant yang disesuaikan pada wanita bertubuh ideal. Diujicobakan pada wanita yang bertubuh ideal berusia 25 tahun, dengan tinggi badan $165 \mathrm{~cm}$ dan berat badan $57 \mathrm{~kg}$. Instrumen yang digunakan dalam penelitian ini adalah kuesioner atau angket. Menurut Sugiyono (2009:199) "kuesioner merupakan teknik pengumpulan data yang dilakukan dengan cara memberi seperangkat pertanyaan atau penyataan tertulis kepada responden untuk dijawabnya".

Skala yang digunakan berupa skala Likerts. Menurut Sugiyono (2009:135) "Skala Likerts adalah jawaban setiap item instrumen yang menggunakan skala Likerts mempunyai gardisi dari sangat positif sampai sangat negatif'. Instrumen pada penelitian ini berisikan 4 pilihanjawaban, yaitu: Sangat sesuai (SS) dengan skor 4, Sesuai (S) dengan skor 3, Kurang Sesuai (KS) dengan skor 2, Tidak Sesuai (TS) dengan skor 1. Untuk melakukan uji coba instrumen, menggunakan validitas logis dan validitas konstruk. Sedangkan kontrol validasi dilakukan dengan menggunakan bahan wol, pengambilan ukuran disesuaikan dengan sistem pola, setiap langkah pola dicek ketepatan ukuran, penilaian dilakukan dengan cara uji coba pola celana Charmant terhadap wanita dewasa Indonesia bertubuh ideal. Penilaian dilakukan oleh 5 orang panelis yang ahli dalam bidang pola busana wanita. Pada setiap item yang sudah sangat sesuai (skor 4), penilaian tidak perlu dilakukan untuk fitting selanjutnya.

Teknik analisa data yang digunakan analisa statistik deskriptif. Menurut Arikunto (2010:227) mengatakan bahwa "statistik deskriptif merupakan statistik yang bertugas untuk mendeskripsikan atau memaparkan gejala hasil penelitian".

Dalam penelitian ini menggunakan perhitungan rumus persentase :

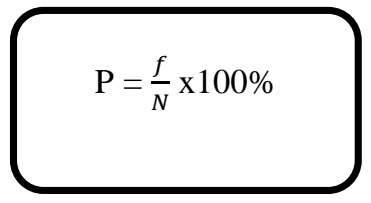

Keterangan:

$\mathrm{P}=$ Persentase

$\mathrm{F}=$ Jumlah skor dari panelis

$\mathrm{N}=$ Jumlah banyak skor 


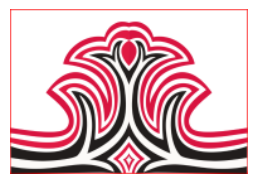

Data diolah menggunakan Microsoft Excel, hasil yang diperoleh dikelompokkan dalam 5 kategori standar penilaian yang dikemukakan oleh Arikunto (2010:44) yaitu:

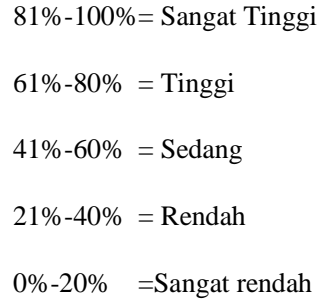

\section{HASIL DAN PEMBAHASAN}

\section{Hasil}

Berdasarkan hasil analisis data yang telah dilakukan, maka terdapat beberapa kelemahan pada pola celana sistem Charmant pada wanita dewasa Indonesia bertubuh ideal.

Kelemahan pola celana sistem Charmant pada wanita dewasa Indonesia bertubuh ideal, diantaranya:

1) Lingkar duduk dengan hasil penilaian ( modus 2 , median 2, persentase $60 \%$ ),

2) Tinggi pesak, dengan hasil penilaian (modus 2, median 2, persentase $50 \%$ ). Rata-rata data dengan modus 3 , median 3 , persentase $74 \%$ ).

Cara memperbaikipola celana sistem Charmant pada wanita dewasa Indonesia bertubuh ideal adalah dengan cara penyesuaian. Penyesuaian pola dilakukan dengan menggunakan tanda pola. Tanda pola yang digunakan dalam memperbaiki pola sesuai dengan pendapat Ernawati (2008:249) yaitu memperbesar pola dengan tanda ////// mengecilkan pola ditandai dengan xxxxxx. Berikut adalah cara penyesuaian pola celana sistem Charmant pada wanita dewasa Indonesia bertubuh ideal setelah fitting 1, memperbaiki pola sesuai kelemahan diatas dengan cara sebagai berikut:

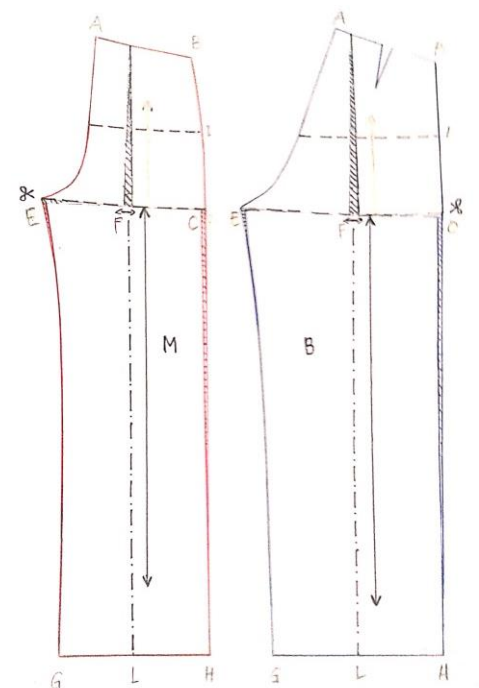

Gorga Jurnal Seni Rupa

Volume 08 Nomor 02 Juli-Desember 2019 p-ISSN: 2301-5942 | e-ISSN: 2580-2380

\section{Gambar 1. Hasil Penyesuaian Pola Lingkar Duduk (Sumber: Aldrich, 2015:180)}

Cara memperbaikinya yaitu tentukan garis lingkar duduk (E-C) dan digunting lalu pada bagian lipatan celana (titik F) dikembangkan dan tambahkan ukuran lingkar duduk sebanyak $1 \mathrm{~cm}$ depan dan belakang, setelah itu perbaiki garis sisi celana.

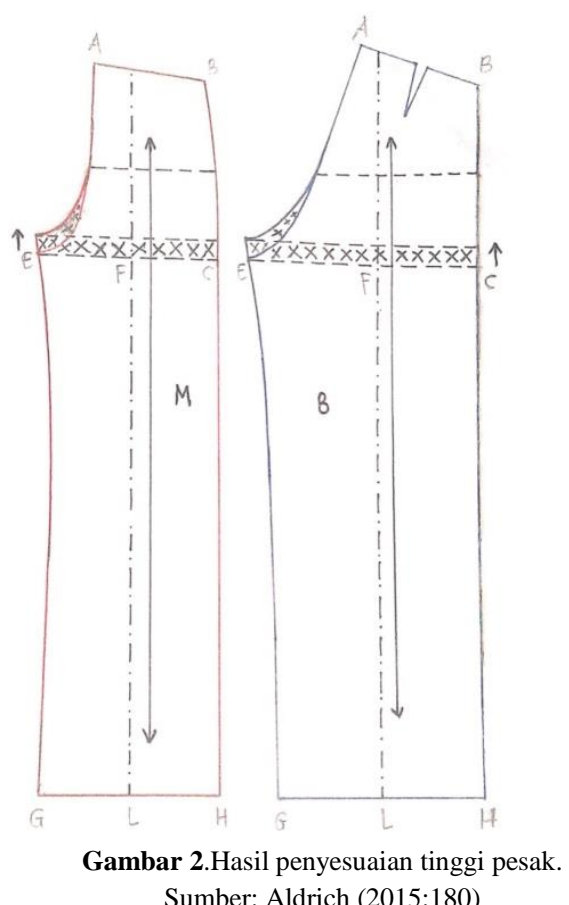

Cara memperbaikinya:

Cara memperbaikinya yaitu dengan mengurangi tinggi pesak (E-C) sebanyak $3 \mathrm{~cm}$. kemudian perbaiki garis pesak dan garis sisi celana.

Dari uraian diatas dapat dilihat bahwa pola celana sistem Charmant pada fitting I berdasarkan nilai modus, median dan persentase , terdapat kelemahan sebanyak 2 item yaitu lingkar duduk dan tinggi pesak. Kesesuaian pola celana sistem Charmant terlihat setelah memperbaiki pola dan dilakukan fitting II semua item berdasarkan modus, median dan persentase dinilai sangat sesuai oleh para panelis, yang digunakan pada wanita dewasa Indonesia bertubuh ideal. Jadi, berdasarkan penilaian pada fitting II pola celana sistem Charmant digolongkan kedalam kategori sangat tinggi 


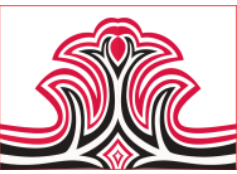

dan dapat digunakan pada wanita dewasa Indonesia bertubuh ideal.

\section{Pembahasan}

Pada proses penelitian pola celana sistem Charmant terlebih dahulu dilakukan pengambilan ukuran pada model, kemudian membuat pola dan menganalisa pola sesuai dengan ukuran dan sistem pembuatan pola tersebut. Sebelum membuat pola ada beberapa hal yang harus diperhatikan dan dikuasi untuk menghasilkan pola yang bagus dan sesuai. Menurut Widjiningsih (1994 : 4) mengatakan "Cara mengambil macam-macam jenis ukuran harus tepat dan cermat, cara menggambar bentuk tertentu harus luwes dan tidak ada keganjilan pada bentuk yang dibuat, perhitungan pecahan dari ukuran yang ada dalam konstruksi secara cermat dan tepat".

\section{KESIMPULA DAN SARAN}

\section{Kesimpulan}

Berdasarkan analisis data dan pembahasan maka peneliti dapat mengambil kesimpulan sebagai berikut:

Kelemahan pola celana sistem Charmant pada wanita dewasa Indonesia bertubuh ideal setelah melakukan fitting I yaitu: Lingkar duduk sempit $4 \mathrm{~cm}$, tinggi pesak panjang $3 \mathrm{~cm}$. Memperbaiki pola celana sistem Charmant. Perbaikan pola celana wanita Indonesia dewasa bertubuh ideal sistem Charmant yang meliputi, lingkar duduk dan tinggi panggul sesuai dengan kelemahan dan nilai yang diberi panelis.

Berdasarkan hasil penelitian kesesuaian pola celana sistem Charmant untuk wanita dewasa Indonesia bertubuh ideal didapat setelah kelemahan dan cara perbaikan pola celana sistem Charmant diketahui, sehingga terdapat beberapa rumusan pola yang perlu disesuaikan dengan wanita dewasa Indonesia betubuh ideal.

\section{Saran}

Berdasarkan hasil penelitian yang telah disimpulkan tersebut, maka peneliti memberikan saran sebagai berikut:

Bagi mahasiswa:

Bagi mahasiswa yang melakukan penelitian eksperimen sebaiknya menggunakan bahan yang sama saat melakukan fitting 1 dan fitting 2 , karena perbedaan bahan akan mempengaruhi hasil dalam pembuatan celana.

Bagi dosen:
Gorga Jurnal Seni Rupa

Volume 08 Nomor 02 Juli-Desember 2019

p-ISSN: 2301-5942 | e-ISSN: 2580-2380

Bagi dosen yang mengajar pola dapat menggunakan pola celana sistem Charmant untuk matakuliah Busana wanita karena pola celana Charmant sangat praktis digunakan.

\section{DAFTAR RUJUKAN}

Aldrich, Winifred. (2016). Terampil Merancang Pola Busana Wanita Dengan Sistem Metric. Jakarta: PT BPK Gunung Mulia.

Arikunto, Suharsimi. (2010). Prosedur Penelitian Edisi Revisi. Jakarta: PT Rineka Cipta.

Charmant. (1990). Pola Dasar Pakaian Anak-anak dan Wanita. Jakarta: PT.Dian Rakyat.

Ernawati, dkk. (2008). Tata Busana Jilid 2. Jakarta: Direktorat Pembinaan Sekolah Menengah Kejuruan.

Haswita, Syafri. (2000). Konstruksi Pola Busana Wanita. Padang: Penerbit DIP Universitas Negeri Padang.

Porrie, Muliawan, (2003). Konstruksi Pola Busana Wanita. Jakarta: PT.BPK Gunung Mulia.

Pratiwi, Djati. (2001). Pola Dasar dan Pecah Pola Busana. Yogyakarta: Pustaka Pelajar.

Sugiyono. (2009). Metode Penelitian Pendidikan Pendekatan kuantitatif, kualitatif, dan $R \& D$. Bandung: CV Alfabeta.

Wancik, M.H. (1996). Bina Busana I Pelajaran Menjahit Pakaian Wanita. Jakarta: PT Gramedia.

Widjiningsih, Sri Wisdiati, Eny Zuhni Khayati. (1994). Konstruksi Pola Busana. Yogyakarta: IKIP Yogyakarta. 